\title{
İŞYÜKÜ FAZLALIĞININ YAŞAM KALİTESİ ÜZERİNDEKİ ETKİSINDE İŞ- AİLE ÇATIŞMASININ ARACI ROLÜ: SAĞLIK SEKTÖRÜNDE BİR UYGULAMA
}

Fuat KORKMAZER ${ }^{1}$

Ali AKSOY 2
Received Date (Başvuru Tarihi):

Accepted Date (Kabul Tarihi):

Published Date (Yayın Tarihi):
$21 / 04 / 2020$

$19 / 05 / 2020$

$25 / 06 / 2020$

Çalıșmada ilk yazar Sorumlu Yazar (Corresponding Author) rolündedir.

ÖZ

\section{Anahtar Kelimeler: \\ İş Yükü Fazlalı̆ğ \\ İş- Aile Çatışması \\ Yaşam Kalitesi}

JEL Kodlarn:

M10,

M12
Bu çalışmada, iş yükü fazlalığı algısının yaşam kalitesi üzerindeki etkisinde iş- aile çatışmasının aracı rolünün ortaya konulması amaçlanmıştır. Bu çalışmanın konusu belirlenirken, ilgili değişkenlerin çalışanların motivasyonuna olumlu katkı sağlayacak şekilde dengeli olması gerektiği gerçekliğinden hareket edilmiştir. Bu amaçla TRB-2 bölgesindeki (Van, Muş, Bitlis, Hakkâri) Sağlık Bakanlı̆̆l'na bağll devlet hastanelerinde çalışanlara bir anket uygulanmıştır. Anket, İş Yükü Fazlalığ Ölçeği, WHOQOL-BREF-TR Yaşam Kalitesi Ölçeği ve Işs-Aile Çatışması ölçeklerinden oluşmaktadır. Elde edilen veriler, yapısal eşitlik modeli (YEM) ve karşılaştırmalı istatistiki analizlere tabi tutularak

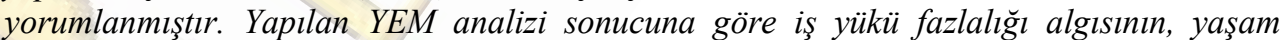
kalitesini negatif yönde çok düşük düzeyde etkilediği, işten aileye çatışma ve aileden işe çatışmayı pozitif yönde etkilediği sonucuna ulaşılmıştır. İş̧en aileye ve aileden işe çatışmanın ise yaşam kalitesini negatif yönde etkilediği sonucuna ulaşılmıştır.

$\begin{array}{lll}\text { Keywords: } & \text { Work Load Balance } & \text { Quality of Life } \\ \text { JEL Codes: } & \text { M10 } & \text { M12 }\end{array}$

\footnotetext{
* Bu çalışma, “İş Yükü Fazlalığı Algısının Yaşam Kalitesi Üzerindeki Etkisi: İş- Aile Çatışmasının Aracı Rolü” isimli doktora tezinden özetlenmiştir.

${ }^{1}$ Dr. Öğr. Üyesi, Muş Alparslan Üniversitesi, f.korkmazer@alparslan.edu.tr,

2 Prof. Dr., İnönü Üniversitesi, ali.aksoy@inonu.edu.tr,

https://orcid.org/0000-0002-2734-7309 https://orcid.org/0000-0001-6234-0631
} 


\section{EXTENDED ABSTRACT}

\section{THE MEDIATING ROLE OF WORK- FAMILY CONFLICT ON THE EFFECT OF WORKLOAD OVERVIEW ON THE QUALITY OF LIFE: AN IMPLEMENTATION IN THE HEALTH SECTOR}

\section{LITERATURE}

\subsection{RESEARCH SUBJECT}

The study, which covers a significant part of daily time, is important because it leads the life of the individual and his family. Therefore, emotions, meanings and values for the study gain importance. In the life of people, the bonds outside of work are continuing with family, friends, relatives and non-governmental organizations. While establishing these ties, the most important issue is the relations with people's families. For this reason, people's expectations regarding life are related to the jobs they spend most of their daily lives or their families.

The perception of the individual that the work undertaken at the institution where he works is above the normal is called workload. For most jobs, it is possible to say that this concept has abstract content based on perception (if the natural burden of the work is not calculated) (Keser, 2006). Workload excess is an imperative that an individual performs more than he / she can do in the normal timeframe and with his talents (Yüksel 2003). One of the leading problems of today's business world is the conflicts between family and work. The fact that the individual's work is intense affects family lives negatively and reduces both his happiness and his family's happiness. Giving importance to the job neglects the family or giving importance to the family results in neglect of the job. Today, as a result of rapid developments in the field of medicine, it is aimed to increase the quality of life of individuals. In line with this goal, there is an increasing effort to measure the quality of life and wellbeing (Yıldırım \& Hacıhasanoğlu, 2011). In measuring health well-being, the concept of quality of life has been developed, which shows the level of the individual's functional status (Testa and Simonson, 1996).

The Theory of Conservation of Resources (COR) is an approach that may be useful in understanding the impact of workload excess on quality of life and work-family conflict levels (Hobfoll, 1989). According to the theory, the resources that are valuable for individuals are categorized in four groups. These resources are: material resources, conditions, personal characteristics and energy (Hobfoll, 1989). According to this theory; individuals strive to obtain, protect and increase the resources they value. Because as the personal characteristics and social conditions of individuals are improved and protected, the aim is to achieve a successful life for them. Environmental conditions often pose a threat to these resources or cause resources to decrease. This threat is important for individuals because of the values of the resources. In other words, the resources that the person struggles to obtain, protect and increase are valuable both because of the features they possess and the opportunity to obtain new resources for the person (Yurur, 2011). 
Since life is a whole, it is not possible to consider working and living conditions, therefore, work and quality of life separate. This is due to the close interaction between work and living conditions (Schulze 1998). Health workers are satisfied with their profession as they help people in need of health services, and this satisfaction ensures that the employee experiences job satisfaction. As a result of the employees feeling themselves as part of the workplace, it is possible that they improve positively in performance and work efficiency, with increased job satisfaction.

\subsection{RESEARCH PURPOSE AND IMPORTANCE}

In the professions that directly serve people, the human element has an important place in the quality of the service. Low quality of life is more common in these professions, which are worked face to face with people (Barron, West 2007; Kaçmaz 2005). The low quality of life in healthcare workers, workload density, care given to severe patients, relationship and distribution of duties at work, disturbed sleep patterns, night bouts, and dealing with relatives (French et al., 2000; Kaçmaz 2005). Examining the workload and working conditions of health workers is very important in terms of the quality of life of the employees and the quality of the services provided. It is very important to eliminate the problems related to the working conditions of the employees and to increase their quality of life, in order to increase the quality of the health service provided. For this reason, it is important to carry out studies to evaluate the working conditions and quality of life of healthcare professionals.

The main purpose of the research is to investigate the mediating effect of work-family conflict on the effect of perception of overhead on quality of life. The research also tested whether the demographic information of healthcare workers made any difference in terms of excessive workload, quality of life, and work-family conflict.

\subsection{CONTRIBUTION of the ARTICLE to the LITERATURE}

There are no studies in the literature that examine the issues of workload excess, quality of life and work-family conflict together. To pioneer the creation of a literature on the subject and to pave the way for further research on the subject in the future. It will benefit the managers in terms of taking measures according to the results obtained by doing such studies in health institutions. Managers will be able to learn about their employees' workload, quality of life, and levels of work-family conflict, and gain insight into factors that will reduce their workload and work-family conflict and improve their quality of life.

\section{DESIGN AND METHOD}

\subsection{RESEARCH TYPE}

The study is an empirical study based on valid and reliable data collected on the questionnaire with questionnaire testing and other measurement tools. 


\subsection{RESEARCH PROBLEMS}

The problem of this study is that work perception of workload, quality of life and work-family conflict are balanced in a way to contribute positively to employees in an organization.

\subsection{DATA COLLECTION METHOD}

In order to investigate the subject, a questionnaire consisting of four parts was conducted. In the first part of the questionnaire, there are questions regarding the demographic information of the participants. In the second part, a questionnaire consisting of workload excess scale, work-family conflict scale and quality of life scale was used.

\subsection{QUANTITATIVE/QUALITATIVE ANALYSIS}

The data obtained in the study were analyzed at 95\% confidence level in SPSS 21 package program. In addition, Structural Equation Model (SEM) was analyzed with the Amos 23 package program for the relationship between workload excess, quality of life and work-family conflict scales. The normality test of the scale scores in the study was done with the Kolmogorov-Smirnov test. Since all scales did not show normal distribution $(\mathrm{p}<0.05)$, Spearman correlation, Mann Whitney, Kruskal Wallis tests, which are non-parametric test techniques, were used. The relationship between scale scores in the study was analyzed with the Spearman correlation test, and the scale scores differing according to demographic characteristics were analyzed with Mann Whitney and Kruskal Wallis tests.

\subsection{RESEARCH MODEL}

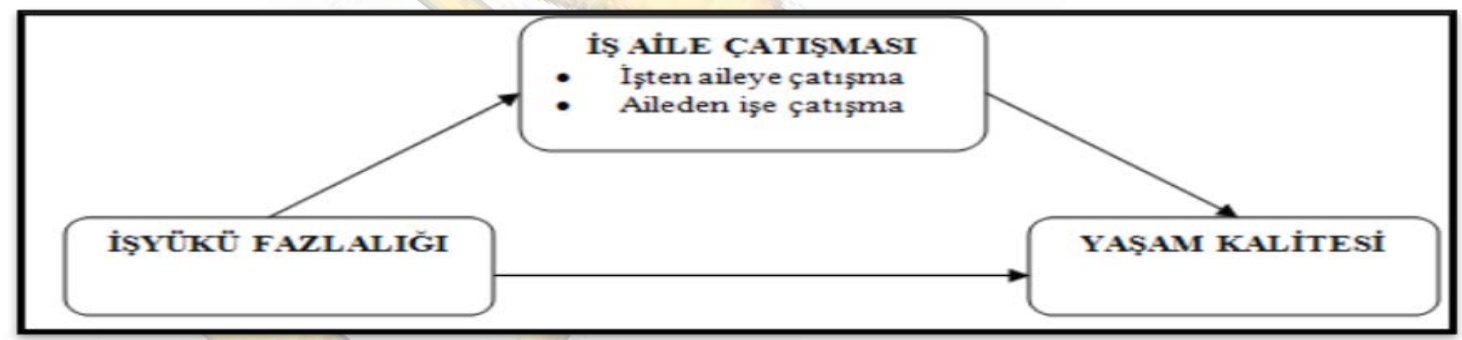

\subsection{RESEARCH HYPOTHESES}

$\boldsymbol{H}_{1}$ : Work-family conflict has a mediating role in the effect of the perception of workload on quality of life.

$\mathbf{H}_{2}$ : Perception of workload excess affects quality of life.

$\mathbf{H}_{3}$ : Perception of workload excess affects conflict from work to family.

$\boldsymbol{H}_{4}$ : Perception of workload excess affects family to work conflict.

$\boldsymbol{H}_{5}$ : Conflict from work to family affects the quality of life.

$\boldsymbol{H}_{6}$ : Family-to-work conflict affects quality of life.

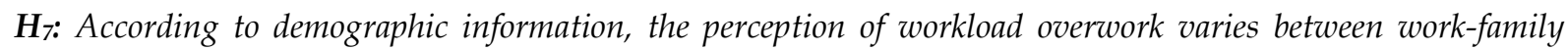
conflict and quality of life. 


\subsection{FINDINGS as a RESULT of ANALYSIS}

A reliability study was conducted regarding the scales used in the study. The Cronbach alpha coefficient of the workload excess scale is $0.815 ; 0,782$ of work-family conflict scale; The quality of life scale was calculated as 0.821 . The fit indexes obtained as a result of testing the structural equation model show that there is a fit between the model and the data. The results show that the model has achieved adequate adaptation. In this case, it can be said that the work-family conflict has an intermediary role in the effect of overwork on quality of life. According to the results of regression analysis with SEM; the excess of workload positively increases the dimensions of work-to-family conflict and family-to-work conflict. Work-to-family conflict and family-to-work conflict significantly reduce quality of life. According to the correlation analysis between variables; there is a positive moderate relationship between workload and work-to-family conflict and family-to-work conflict. There is a weak negative relationship between workload and quality of life. There is a weak positive relationship between work-to-family conflict and family-to-work conflict. There is a weak negative relationship between work-to-family conflict and family-to-work conflict and quality of life.

\subsection{HYPOTHESIS TEST RESULTS}

H1 hypothesis was accepted.

$\mathrm{H} 2$ hypothesis was rejected.

H3 hypothesis was accepted.

H4 hypothesis was accepted.

H5 hypothesis was accepted.

H6 hypothesis was accepted.

The H7 hypothesis has been partially accepted.

\section{CONCLUSION, RECOMMENDATION AND LIMITATIONS}

\subsection{RESULTS of the ARTICLE}

Workload excess; it significantly increases the dimensions of work-to-family conflict and family-to-work conflict. Work-to-family conflict and family-to-work conflict significantly reduce the quality of life. It was determined that the work-family conflict significantly mediated the workload over the impact of the quality of life.

As a result of the analysis made to examine the relationship between workload excess and demographic features; in terms of marital status, there is no statistically significant difference in excess workload. There is a statistically significant difference between age, gender, educational background, working time in the profession and institution, title, weekly working time, and the provincial variables studied. As a result of the analysis made to examine the relationship between work-family conflict and demographic features; in terms of marital status, there is no statistically significant difference in terms of perceptions of work-family conflict. There is a statistically significant difference between age, gender, educational background, working time in the profession and institution, title, 
weekly working time, and the provincial variables studied. As a result of the analysis to examine the relationship between quality of life and demographic features; there was no difference in the participants' assessment of the quality of life factors in terms of age, gender, marital status, working time in the profession and institution, title and way of working.

\subsection{SUGGESTIONS BASED on RESULTS}

- Managers should be informed about work-family conflict and supported by various training and courses offered by educational institutions and consulting firms.

- Health institutions should organize activities in order to increase the sharing of experience for employees to deal with work-family conflict experiences and to deal with conflict.

- It should develop policies in a way that will contribute positively to the protection of employees' resources (material resources, conditions, personal characteristics and energy).

- Processes related to doing things should be examined in order to reduce the overload of the employees.

- In units suitable for flexible working, employees should be ensured to try to reach the quality of life they desire by creating flexible working conditions.

\subsection{LIMITATIONS of the ARTICLE}

Participants in the survey application may have been concerned that the results of the research could be reflected negatively by sharing with the management. Therefore, the possibility of answering questions with some reservations can be considered as the limitation of the study. The fact that the research sample only covers employees in public health institutions and private hospitals are not included in the study restricts the interpretation of the findings throughout the sector. Another limitation is that the study included only the health personnel working in the health institutions affiliated to the Ministry of Health in the city center in the TRB-2 Region. 


\section{GİRIŞ}

İnsanlar bir ailede doğup büyür ve hayatlarının belli bir döneminden sonra da bir iş sahibi olurlar. Günlük zamanın önemli bir kısmını kapsayan çalışma, bireyin ve ailesinin hayatını devam ettirdiği için önemlidir. Bundan dolayı çalışmaya yönelik duygu, anlam ve değerler de önem kazanmaktadır. İnsanların hayatında iş dışındaki bağları, aile, arkadaş, akraba ve sivil toplum kuruluşları ile süreklilik arz etmektedir. $\mathrm{Bu}$ bağlar kurulurken, en önemli husus insanların aileleri ile olan ilişkilerdir. Bu nedenle kişilerin hayata dair beklentileri günlük yaşamlarının büyük bir kısmını geçirdikleri işleri ya da aileleriyle ilgili olmaktadır. Günümüz iş dünyasının önde gelen sorunlarından biri de aile ile iş arasındaki çatışmalardır. Çatışma, bireylerin sorunlarından rahatsızlık duymaları durumunda ortaya çıkmaktadır. Bireyin işlerinin yoğun olmasının aile hayatlarını olumsuz etkilemesi hem kendi mutluluğunu hem de ailesinin mutluluğunu azaltmaktadır. Ya da ailevi sorunlar veya ailelere zaman harcanması nedeniyle iş yaşamında sorunlar meydana gelmektedir. İşe önem verilmesi ailenin ihmali veya aileye önem verilmesi işin ihmali sonucunu doğurmaktadır. Yaşam bir bütün olduğundan, çalışma ve yaşam koşullarını, dolayısı ile çalışma ve yaşam kalitesini birbirinden ayrı düşünmek mümkün olmamaktadır. Bu durum, iş ve yaşam koşulları arasında sıkı bir etkileşimin olmasından kaynaklanmaktadır (Schulze 1998). Mesleki tatmin, çalışanın yaşam kalitesini olumlu yönde etkileyen bir kavram iken iş yaşamı sürecinde karşılaşılan zorlu süreçler ise yaşam kalitesini olumsuz yönde etkilemektedir. Sağlık çalışanları, sağlık hizmeti ihtiyacı olan kişilere yardım ettiğinden mesleğinden hoşnut olmakta, bu hoşnutluk çalışanın iş doyumu yaşamasını sağlamaktadır. Çalışanların kendilerini iş yerinin bir parçası olarak hissetmeleri sonucunda performans ve iş verimliliğinde olumlu yönde gelişmeleri, iş doyumlarının artması ile mümkündür.

Doğrudan insana hizmet eden doktor, hemşire, öğretmen, polis, avukat gibi mesleklerde insan unsuru hizmetin kalitesinde oldukça önemli bir yere sahiptir. İnsanlarla yüz yüze çalışılan bu mesleklerde yaşam kalitesi düşüklüğü daha sık görülmektedir (Barron, West 2007; Kaçmaz 2005). Sağlık çalışanlarında yaşam kalitesi düşüklüğüne, iş yükü yoğunluğu, ağır hastalara verilen bakım, iş yerinde 
yaşanan ilişki ve görev dağılımı sorunları, bozulan uyku düzeni, gece nöbetleri, hasta yakınlarıyla uğraşılması yol açmaktadır (French vd, 2000; Kaçmaz 2005). Sağlık çalışanları rutin çalışma günleri ve saatleri dışında çalışmakta, hayati tehlikesi olan insanlara hizmet sunmakta, hasta ve hasta yakınlarının büyük beklentileri ile karşılaşmaktadır. Sağlık çalışanları yoğun stres altında çalışmaktan ruhsal olarak etkilenmekte ve bu durum yaşam kalitelerini olumsuz olarak etkileyebilmektedir (Yıldırım, Hacıhasanoğlu 2011). Çalışanların çalışma koşullarına ilişkin sorunların giderilmesi ve yaşam kalitelerinin arttırılması, verilen sağlık hizmetinin kalitesinin artırılması açısından oldukça önemlidir. Bu nedenle sağlık çalışanlarının çalışma koşulları ve yaşam kalitesini değerlendirmeye yönelik çalışmaların yapılması önem kazanmış ve günümüzde bu konu üzerinde hassasiyetle durulmaya başlanmıştır. Sağlık çalışanlarının iş yükü fazlalığı ve çalışma koşullarının incelenmesi, çalışanların yaşam kalitesi ve sunulan hizmetlerin kalitesi açısından oldukça önem taşımaktadır.

Bu çalışma konusu belirlenirken yukarıdaki değiş̧kenlerin (iş yükü fazlalığı algısı, yaşam kalitesi ve iş-aile çatışması) aynı anda bir organizasyonda çalışanların motivasyonuna olumlu katkı sağlayacak şekilde dengeli olması gerektiğinden hareket edilmiştir. Bu bağlamda bu değişkenlerin birbirleriyle olan ilişkisini tespit etmeye yönelik bir çalışma yapmak amaçlanmış, çalışma iki bölümde ele alınmıştır. İlk bölümde iş yükü fazlalığı iş-aile çatışması ve yaşam kalitesi kavramları ve teorileri irdelenmiştir. İkinci bölümde ise bir alan çalışmasına yer verilmiştir. Bu bölümde yukarıda bahsedilen bu kavramlar yapısal eşitlik modeli (YEM) ile analiz edilmiştir.

\section{2. İŞYÜKÜ FAZLALIĞI, İŞ- AİLE ÇATIŞMASI VE YAŞAM KALİTESİ}

\section{1. İş Yükü Fazlalığı}

Bireyin çalıştığı kurumda kendisine yüklenen işin normalin üzerinde olduğuna yönelik algısına iş yükü denir. Çoğu iş için, bu kavramın algıya dayalı soyut içeriğe sahip olduğunu söylemek (işin doğal yükü hesaplanmamış ise) mümkündür (Keser, 2006). İş yükü, bireyin kişi başına ve birim zamana düşen iş sebebiyle baskı altında tutulması anlamına da gelmektedir. İş yükü, çalışan açısından fazlasıyla önem arz eden bir değişkendir. Tükenmişlik sendromu ile ilgili yapılan 
çalışmalarda, bireyin ağır iş yükü altında kalması tükenmenin en temel sebeplerden birisi olarak tespit edilmiştir. Bir başka ifade ile aşırı iş yükü, işten kaynaklı stres kaynakları arasında en önemli ve en fazla rastlanan etkenlerdendir (Karoshi,2003: 3).

İş yükünü çeşitli özellikler belirlemektedir. Bunlar (Wallace 1999):

- Mesaiye kalmayı ve hafta sonu çalışmayı gerektiren görevler,

- Teslim tarihleri,

- Zaman baskisi,

- Bilgi fazlalı̆̆1,

- Fazladan ilgilenilen insan sayısıdır.

İş yükü fazlalığı, bireyin normal zaman diliminde ve yetenekleri ile yapabileceğinden fazla bir işi yapmasının oluşturduğu zorunluluktur (Yüksel 2003). İşletmeler, çalışanlara makul bir iş yükü tahsis edilmesini sağlamalıdır. Makul iş yükünü belirlemek için, yöneticiler ve denetçiler şunları sağlamalıdır (Syed vd., 2011):

- Görevler, çalışanlara makul ölçüde beklenenleri aşmayacak şekilde tahsis edilmelidir.

- Sistemler, çalışma saatleri ve iş yükü arasındaki ilişkiyi görmek için bireysel çalışanların çalışma saatlerini izlemek üzere geliştirilmelidir. Çalışanlar çalıştıkları iş yerlerine göre düzenli olarak çalışırsa teknoloji değişikliği, sorumluluk veya ekstra kaynak sağlanmalıdır.

- Bir çalışan işten ayrılırsa yerine başkasını yerleştirme ile ilgili takvim genellikle üç ay içinde hafifletilmelidir.

Çalışanların yerine getirmesi gereken iş yükü, en uygun ve ideal olanın üzerinde olduğunda aşırı iş yükü olarak ifade edilmektedir. Yapılan işin veya yerine getirilecek görevin, ağır veya fazlalığı, subjektif bir durumdur. Aşırı iş yükü, niceliksel ve niteliksel iş yükü şeklinde iki grupta incelenebilir (Özkalp, Kırel 2013):

Niceliksel İş Yükü: Belirli bir iş için çalışanın zamanının yetersiz olması, belirli bir zaman diliminde yapılması gereken işlerin fazlalığı ve bu iş koşullarının ağır ve 
yorucu olması durumunda söz konusu olmaktadır. Birey üzerinde olumsuz bir etki oluşturan zaman baskısı, birey işi yapmak için gerekli olan yetenek ve beceriye sahip olduğu halde işi yapış şeklini olumsuz etkilemektedir.

Niteliksel İş Yükü: Bu iş yükünde, işin gerekleri ile çalışanın sahip olduğu özellikler arasında, çalışanı olumsuz etkileyen bir dengesizlik söz konusudur. Bu durumda, çalışan bilgi, beceri ve bireysel nitelik gibi işin gereklerine tamamen sahip olmadığından, çalışılan iş işi yapacak kişiye zor gelecektir (Eroğlu 2007). Yapılan işin içerik ve kapsamı, çalışanın yaşadığı rol çatışması ve rol belirsizlikleri iş yükünün meydana getirilmesinde etkileyici olmaktadır (Lydon vd. 1997).

\section{1. İş-Aile Çatışması}

Çatışma, iki ya da daha fazla birey veya grubun; hedef, istek ve amaçlarının uyum içerisinde olmamasıdır. Başka bir tanıma göre çatışma, birey ve gruplar arasındaki anlaşmazlık ya da sürtüşmeler sonucun oluşan duygusal ortamlardır (Çarıkçı, Çelikkol 2009). Araştırmacıların çoğunun temel aldığı iş-aile çatışması tanımlaması Greenhaus ve Beutell (1985) tarafından yapılmıştır. Greenhaus ve Beutell (1985)'e göre; iş-aile çatışması iş ve aileden kaynaklı rol taleplerinin bazı yönleriyle uyumlu olmaması şeklinde tanımlanmaktadır.

İş-aile çatışmasında etkili olan faktörler; Kişisel faktörler, işle ilgili faktörler ve aileyle ilgili faktörler olmak üzere üç başlık altında incelenmektedir.

Kişisel Faktörler: Her insanın kendine has bir fıtrata sahip olması bireylerin olaylar karşısında göstermiş oldukları tepkilerin de farklı olmasına yol açabilmektedir. Bu farklılıklar olaylara verilen tepkide farklılık, olaylara karşı fazla hassas olma, bazı şeylerin önemsenmesi bazılarının da önemsememesi şeklinde olabilmektedir. Kişisel faktörler iş-aile çatışmasına yön vermekte ve şiddetini belirlemekte de etkili olmaktadır. İş-aile çatışmasının ortaya çıkma nedenlerini ve şiddetini belirleyebilen kişisel faktörler arasında cinsiyet, eğitim düzeyi, yaş, medeni durum gibi faktörler yer almaktadır (Keser 2005).

İş İle İlgili Faktörler: Günümüzde çalışanlar, artan işsizlik seviyelerinden dolayı mevcut işlerini korumak için işverenlerin çoğu taleplerine uymayı zorunluluk olarak algılamaktadır. Bu durum iş-aile çatışmasını artırmaktadır. İş hayatındaki bu 
uyum zorunluluğu çalışanları pek çok açıdan olumsuz etkilemekte ve diğer yaşam alanlarında çatışma yaşamalarına neden olmaktadır (Katyayani, Bussareddy 2011). Çalışma saatleri, sık sık fazla mesai yapılması ve düzensiz çalışma şekli iş-aile çatışmasını artıran işle ilgili faktörlerdendir. Aynı zamanda esnek olmayan ve çalışanın kontrol edemediği çalışma saatleri çatışmayı artırmaktadır (Greenhaus, Beutell, 1985). Diğer taraftan yönetici desteğinin iş-aile çatışmasını azaltmada etkili olduğu yönünde araştırma sonuçları da mevcuttur (Fu, Shaffer 2000).

Aile İle İlgili Faktörler: Anne veya baba olmak bireye sorumluluklar getirdiği için aile ile ilgili etkinliklere daha fazla katılmayı gerekli kılmakta ve bu durum daha fazla iş aile çatışması yaşanmasına sebep olmaktadır. Evde çocuk olması, çocuk sayısı (fazla çocuk-yüksek düzeyde iş aile çatışması), çocukların yaşları (çocuğun küçük olması -yüksek düzeyde iş aile çatışması) iş aile çatışmasını etkilemektedir (Madsen 2003).

\subsection{Yaşam Kalitesi}

Yaşam kalitesi, kişisel iyilik halini de içine alan fiziksel sağlık durumunun da ötesinde geniş bir kavramdır. Dünya Sağlık Örgütü (WHO) yaşam kalitesini; bireyin kültür ve değerler sistemi içerisinde kendi durumunu algılama biçimi şeklinde tanımlamıştır. Kişinin yaşadığı yerdeki amaçları, beklentileri, standartları ve ilgilerini kapsamaktadır (Yıldırımçakar 2015). Birey koşulları uygun olan çalışma ortamı ve işinden aldığı doyum sayesinde olumlu duygular ile beslenmekte, buna paralel olarak yaşam doyumu ve yaşam kalitesi de yükselmektedir. Yaşam kalitesi kavramı, kişinin fiziksel, duygusal ve sosyal iyilik halini ve yaşamın günlük fonksiyonlarını sürdürebilmesi şeklinde tanımlanmaktadır. Yaşam kalitesi, kişinin yaşadığı toplumun sunduğu imkânlardan yararlanması, toplumsal beklentileri ve temel ihtiyaçları karşılanması gibi birçok yaşam alanından söz etmektedir. Yaşam kalitesi kavramı, bahsedilen bu alanların geliştirilmesi ve düzenleme yapılması açısından önemlidir (Şenol, Türkay 2006).

Yaşam kalitesinin algılanmasında kişiler arası farklılıklar görülmektedir. Bunu ayağı kırılan bir insan üzerinden değerlendirecek olursak; ayağı kırılan bir insanın yaşadığı bu durumu fiziksel olarak değerlendirmeyerek, kendisi için çok önemli bir 
toplantının kaçırılmasına neden olarak görmesi neticesinde yaşadığı olumsuz etki, yaşam kalitesi ile ilgilidir. Fakat tam tersi bir durumda, ayağı kırılan bu insanın tezini bitirmek için bir imkân yakalayacağı için bu durum kişiyi mutlu edecekse yaşam kalitesi olumlu olabilecektir.

İş yükü fazlalığının, yaşam kalitesi ve iş-aile çatışması düzeylerine etkisinin anlaşılmasında Kaynakların Korunması Teorisi, (COR) yararlı olabilecek bir yaklaşımdır (Hobfoll, 1989). Kaynakların korunması teorisine göre kişiler için değeri olan kaynaklar dört başlık altında toplanmaktadır. Bu kaynaklar: Maddi kaynaklar, koşullar, kişisel özellikler ve enerjidir (Hobfoll 1989). Bu teori; bireylerin değer verdikleri kaynakları elde etme, koruma ve artırma amacıyla çabaladığını savunmaktadır. Çünkü bireylerin kişisel özellikleri ve sosyal koşulları iyileştikçe ve korundukça, kendileri için başarılı bir yaşam sağlama amacı gerçekleşmektedir. Çevrede oluşan koşullar genellikle bu kaynaklar için tehdit oluşturmakta ya da kaynakların azalmasına sebep olmaktadır. Bu tehdit, bireyler için kaynakların taşıdığı değerleri nedeniyle önem arz etmektedir. Başka bir ifadeyle kişinin elde etme, koruma ve artırma amaciyla mücadele ettiği kaynaklar, hem sahip oldukları özellikler hem de kişiye yeni kaynaklar elde etme imkânı sundukları için değerlidir (Yürür 2011).

Bireyler açısından yaşam; kişisel, iş ve aile yaşantısı anlamında bir bütünlük ifade etmektedir. Bunun için iş ve aile yaşamında bir denge kurulması, bireyin ailesi ve sosyal çevresiyle uyum içerisinde bulunmasını ve dolayısıyla kaliteli bir yaşam sürmesini sağlamakla birlikte, işveren beklentilerinin de karşılanmasını sağlayacaktır. Teoriye göre: bireyin sahip olduğu kaynakların tehdit edilmesi, kaynakların yitirilmesi ya da eldekilerin harcanması halinde yerine yeni kaynaklar konmaması durumunda bireyler stres yaşamaktadırlar (Hobfoll 2001). Buna göre birey, çalışma yaşamında önemli ölçüde zaman, enerji ve ailesi için ayırması gereken zamanı tükettiği halde harcadığı kaynakların yerine yeni kaynaklar temin edemediği hatta sürekli kaynak kaybetmeye devam ettiğinde tükenmişlik yaşayacaktır (Yürür 2011). 


\section{YÖNTEM}

\subsection{Araştırmanın Amacı ve Hipotezleri}

Araştırmanın temel amacı, iş yükü fazlalığı algısının yaşam kalitesi üzerindeki etkisinde iş-aile çatışmasının aracı etkisinin araştırılmasıdır. Araştırmada ayrıca sağlık çalışanlarının demografik bilgilerinin ve mesleki özelliklerinin iş yükü fazlalığı, yaşam kalitesi ve iş-aile çatışması boyutlarında farklılık oluşturup oluşturmadiğı test edilmiştir.

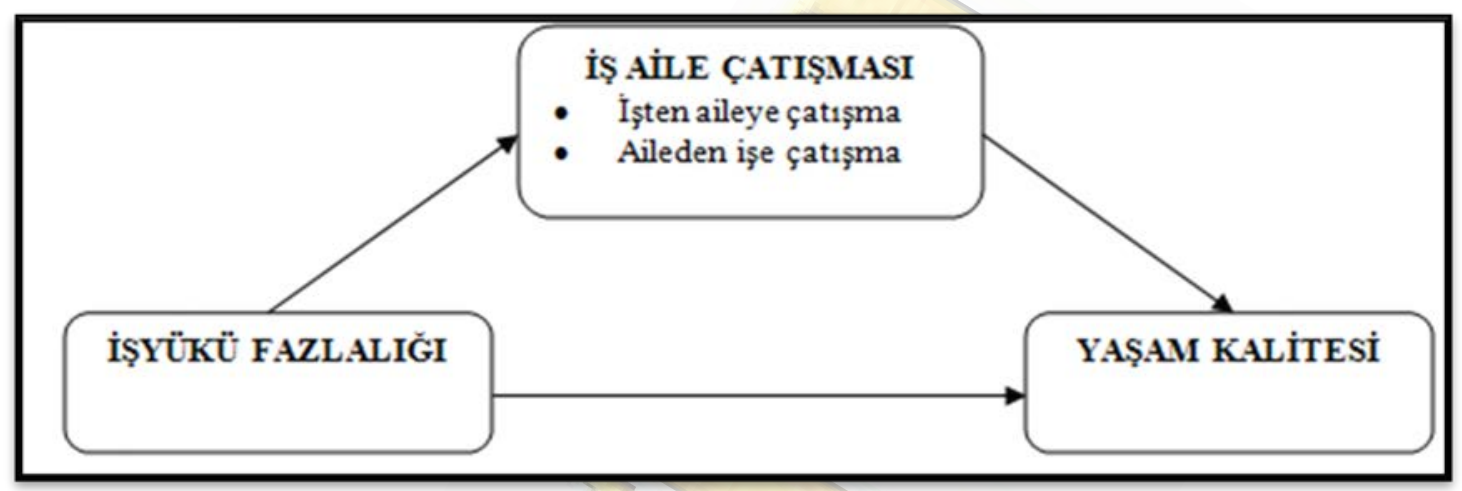

Şekil 1. Araştırma Modeli

Araştırmanın temel hipotezleri aşağıdaki gibidir;

H1: İşyükü fazlalığı algısının yaşam kalitesi üzerindeki etkisinde iş-aile çatışmasının aracı rolü vardır.

H2: İş yükü fazlalı̆̆ı algısı yaşam kalitesini etkiler.

H: İş yükü fazlalı̆̆ı algısı işten aileye çatışmayı etkiler.

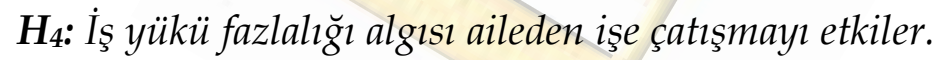

$\boldsymbol{H}_{5}$ : İşten aileye çatışma yaşam kalitesini etkiler.

H6: Aileden işe çatışma yaşam kalitesini etkiler.

H7: Demografik bilgilere göre, iş yükü fazlalı̆̆ı algısı farklılık gösterir.

Hs: Demografik bilgilere göre, iş-aile çatışması farklılık gösterir.

H9: Demografik bilgilere göre, yaşam kalitesi algısı farklılık gösterir. 


\subsection{Araştırmanın Evren ve Örneklemi}

Araştırma evrenini, TRB-2 Bölgesinde il merkezindeki Sağlık Bakanlığı'na bağlı sağlık kuruluşlarında Mayıs- Ekim 2017 tarihleri arasında çalışan 4463 sağlık personeli oluşturmaktadır. Bu kuruluşlar; Van Bölge Eğitim ve Araştırma Hastanesi, Muş Devlet Hastanesi, Bitlis Devlet Hastanesi ve Hakkâri Devlet Hastanesi dir. Örneklemin evreni iyi temsil etmesinin gerekliliği dikkate alınarak, dört ilde faaliyette bulunan sağlık bakanlığına bağlı devlet hastanesi çalışanları tercih edilmiştir. İlgili hastane yönetimlerinden alınan bilgilere göre toplamda 4463 çalışan (Van Bölge Eğitim ve Araştırma Hastanesinin 2611, Muş Devlet Hastanesinin 980, Bitlis Devlet Hastanesinin 412 ve Hakkâri Devlet Hastanesinin ise 460) bulunmaktadır. Örneklem kapsamında tüm çalışanlara ulaşılarak anket formu uygulanmak istenmiştir. Ancak izin (yıllık, nöbet, hastalık, doğum, mazeret vd.), görevlendirme, dağıtılan anket kayıpları ve anketin cevaplanmak istenmemesi gibi sebepler dolayısıyla sağlık personeline 1550 anket dağıtılabilmiştir. Dağıtılan anketlerin 1143'ü geri dönmüştür. Soru formları incelendiğinde, hatalı ve eksik doldurulan 48 form çalışmaya dâhil edilmemiş olup geriye kalan toplam 995 soru formu analiz kapsamına alınmıştır. Örneklem büyüklüğü \% 95 güven aralığında e= \% 5 hata payı belirlenmiştir (Yazıcıoğlu, Erdoğan 2014).

\subsection{Araştırmanın Yöntemi}

Çalışanların iş yükü fazlalığı düzeylerini tespit etmek için Imoisilinin (1985) geliştirdiği ve Alam'ın (2016) Türkçeye uyarladığı 5 maddeden oluşan iş yükü fazlalığ1 ölçeği kullanılmıştır. Ölçeğin tek bir boyutu bulunmakta ve 5’li Likert şeklinde verileri toplamaktadır. Alam’ın yaptığı Türkçeye uyarlama çalışmasında ölçeğin güvenilirlik katsayısının 0,780 olarak hesaplandığı, doğrulayıcı faktör analizi DFA uyum indekslerinin kabul edilebilir sınırlarda olduğu belirtilmiştir. Çalışanların yaşadığı iş-aile çatışması düzeyini ölçmek için kullanılan ölçek, Netemeyer ve diğerleri (1996) tarafından ortaya konulmuş, Apaydın (2004) tarafından Türkçeye uyarlanmış 10 ifadeden ve iki alt boyuttan oluşmaktadır. Apaydın'ın (2004) yaptığ1 çalışmada 5 ifadeden oluşan işten aileye çatışma boyutu için $\alpha=0.86$ yine 5 ifadeden oluşan aileden işe çatışma boyutu için güvenilirlik katsayısı $=0.82$ olarak 
belirlemiştir. Yaşam kalitesini ölçmek için kullanılan ölçek Dünya Sağlık Örgütü (DSÖ) tarafından geliştirmiş, ölçeğin Türkçe geçerlik ve güvenirliği Fidaner ve diğerleri tarafından (1999) yapılmıştır. Ölçeğin WHOQOL-100 ve WHOQOL-27 formu şeklinde iki sürümü bulunmaktadır. WHOQOL-BREF ölçeği, toplam 26 sorudan meydana gelmiştir. Türkçe geçerlilik çalışmalarında bir ulusal soru eklenmesi sonucu oluşan WHOQOL-BREF-TR 27 sorudan oluşmaktadır.

Saha çalışmasında veriler Mayıs- Ekim 2017 tarihleri arasında toplanmıştır. Veri toplama zamanı 1 Ocak 2020 den önce olduğundan etik kurul izin belgesi gerekmemektedir. Saha çalışması ile ilgili gerekli izinlerin alınması amacıyla yapılan ilk görüşmelerde kurum yetkililerinin yönlendirmesi ve istekleri doğrultusunda, soru formlarının kurum tarafından görevlendirilen personel nezaretinde yürütülmesine karar verilmiştir. Birim yöneticilerinin sürece dâhil olmaları katılımı artırmıştır. Çalışma kapsamında elde edilen veriler SPSS 21 paket programında \%95 güven düzeyinde analiz edilmiştir. Ayrıca iş yükü fazlahı̆ıı, yaşam kalitesi ve iş-aile çatışması ölçeklerinin ilişkisine yönelik Yapısal Eşitlik Modeli (YEM) Amos 23 paket programı ile analiz edilmiştir. Çalışmada ölçek puanları için yapılan normallik testi, örneklem sayısı 50'den büyük olduğundan Kolmogorov-Smirnov testi ile yorumu yapılmıştır. Ölçeklerin tümü normal dağılım göstermedikleri için $(p<0,05)$ nonparametrik test tekniklerinden Spearman korelasyon, Mann Whitney, Kruskal Wallis testleri kullanılmıştır. Çalışmada ölçek puanlarının ilişkisi Spearman korelasyon testiyle, ölçek puanlarının kişisel özelliklere göre farklılık gösterme durumu da Mann Whitney ve Kruskal Wallis testleri ile analiz edilmiştir.

\section{BULGULAR}

\subsection{Yapı Geçerliliği ve Güvenirliğe Yönelik Bulgular}

Çalışmada kullanılan ölçeklere ilişkin güvenirlik çalışması yapılmıştır. Ölçeklerin cronbach alfa katsayılarına bakılarak her bir ölçeğin güvenirliği ayrı ayrı hesaplanmış ve sonuçlar Tablo 1' de gösterilmiştir. 
Tablo 1. Ölçeklere İlişkin Cronbach Alfa Katsayıları

\begin{tabular}{|c|c|c|}
\hline Ölçekler & Madde Sayısı & Cronbach Alfa \\
\hline İş Yükü Fazlalı̆̆ı & 5 & 0,815 \\
\hline İş-Aile Çatışması & 10 & 0,782 \\
\hline İşten Aileye Çatışma & 5 & 0,848 \\
\hline Aileden İşe Çatışma & 5 & 0,779 \\
\hline Yaşam Kalitesi & 27 & 0,821 \\
\hline
\end{tabular}

Tablo 1 incelendiğinde; iş yükü fazlalığı ölçeği için ölçeğin Cronbach alpha katsayısı 0,815; iş-aile çatışması ölçeği için 0,782; yaşam kalitesi ölçeği için 0,821 olarak hesaplanmıştır. Buna göre iş yükü fazlalığı ve yaşam kalitesi ölçeklerinin cronbach alfa değeri 0,80-1,00 aralığında olduğu için ölçeklerin yüksek güvenilirlikte olduğu, iş-aile çatışması ölçeğinin cronbach alfa değeri ise 0,60-0,79 aralığında olduğu için bu ölçeğin oldukça güvenilir olduğu görülmektedir (Alpar 2014). Yapısal eşitlik modelinde ilk önce ölçme modeli (jenerik model) test edilmekte, modelde bir sorunun olmayışı anlaşıldıktan veya sorunlar çözüldükten sonra da yapısal model test edilmektedir. Modelin test edilmesi neticesinde elde edilen uyum indeksleri modeliyle veri arasında uyum olduğunu gösterdiğinde, yapısal açıdan kurulan hipotezler kabul edilmekte; uyum indeksleri model ile veri arasında uyum olmadığını gösterdiğinde ise hipotezler reddedilmektedir (Meydan, Şeşen 2015).

Tablo 2. Araştırma Modeli İçin DFA Sonuçları Uyum İndeksleri

\begin{tabular}{|c|c|c|c|c|}
\hline (Uyum İndeksleri) & Ölçüm & İyi Uyum & Kabul Edilebilir & Sonuç \\
\hline$X^{2} / \mathrm{sd}$ & $\mathbf{2 , 2 8 7}$ & $<3$ & $<4-5$ & İyi Uyum \\
\hline CFI & $\mathbf{0 , 9 5 9}$ & $>0.97$ & $>0.95$ & Kabul Edilebilir \\
\hline RMSEA & $\mathbf{0 , 0 3 6}$ & $<0.05$ & $0.06-0.08$ & İyi Uyum \\
\hline GFI & $\mathbf{0 , 9 1 6}$ & $>0.90$ & $0.89-0.85$ & İyi Uyum \\
\hline AGFI & $\mathbf{0 , 9 0 5}$ & $>0.90$ & $0.89-0.85$ & İyi Uyum \\
\hline RMR & $\mathbf{0 , 0 5 3}$ & $<0.05$ & $0.06-0.08$ & Kabul Edilebilir \\
\hline
\end{tabular}

Tablo 2'ye göre; oluşan sonuçlar modelin yeterli uyum sağladiğını göstermektedir. Bu durumda iş yükü fazlalığının yaşam kalitesi üzerindeki etkisinde iş-aile çatışmasının aracı rolü olduğu söylenebilir. Yapısal Eşitlik Modeli için uyum istatistikleri hakkında değişik parametreler kullanılmıştır. Kullanılması gereken 
parametrelerin hangisi olduğu ile ilgili bir fikir birliği olmasa da, birkaç parametrenin birlikte kullanılması tavsiye edilmektedir. $\mathrm{Bu}$ bağlamda, en az üç uyumluluk (Fit) test grubundan birer tanesi kullanılmalıdır. Bunlardan en sık kullanılanları (Chi-Square Goodness), GFI, AGFI, CFI, NFI, RMR ve RMSEA'dır (Meydan, Şeşen 2015).

Tablo 3. Katılımcıların Mesleki ve Demografik Özelliklerine İlişkin Bulgular

\begin{tabular}{|c|c|c|c|c|c|}
\hline \multicolumn{2}{|c|}{ Özellikler } & $\% \mathbf{N}$ & \multicolumn{2}{|c|}{ Özellikler } & $\% \mathbf{N}$ \\
\hline \multirow[b]{2}{*}{ Cinsiyet } & Kadın & 52 & \multirow{2}{*}{$\begin{array}{l}\text { Medeni } \\
\text { Durum }\end{array}$} & Evli & 54,6 \\
\hline & Erkek & 48 & & Bekâr & 45,4 \\
\hline \multirow{5}{*}{ Yaş } & $18-25$ & 29 & \multirow{5}{*}{$\begin{array}{c}\text { Haftalık } \\
\text { Çalışma } \\
\text { Süresi }\end{array}$} & 40 Saat & 58,6 \\
\hline & $26-30$ & 28,6 & & 41-56 Saat & 24,5 \\
\hline & $31-35$ & 18 & & 57-72 Saat & 13,7 \\
\hline & $36-40$ & 16,6 & & 72 Saat Üzeri & 3,2 \\
\hline & $41+$ & 7,7 & & & \\
\hline \multirow{4}{*}{ Eğitim Durumu } & Lise & 16,7 & \multirow{4}{*}{ Unvan } & Tabip & 9,4 \\
\hline & Ön lisans & 31,4 & & İdari Personel & 14,7 \\
\hline & Lisans & 43,4 & & Tabip Dışı Sağlık & 75,9 \\
\hline & Lisansüstü & 8,5 & & Personeli & \\
\hline \multirow{5}{*}{$\begin{array}{c}\text { Meslekte Çalışma } \\
\text { Süresi }\end{array}$} & 1 Yila Kadar & 13,1 & \multirow{5}{*}{$\begin{array}{c}\text { Kurumda } \\
\text { Çalışma } \\
\text { süresi }\end{array}$} & 1 Yila Kadar & 22,3 \\
\hline & 1-3 Yil & 20,4 & & 1-3 Yil & 30,2 \\
\hline & 4-6 Yil & 21,4 & & 4-6 Yil & 20,3 \\
\hline & $7-10 Y_{11}$ & 15,4 & & 7-10 Y1l & 9,9 \\
\hline & 10 Y1l Üzeri & 29,7 & & 10 Yil Üzeri & 17,3 \\
\hline \multirow{3}{*}{ Çalışma Şekli } & Gündüz & 43,9 & & & \\
\hline & Nöbet Usulü & 7,2 & & & \\
\hline & Gündüz + Nöbet & 48,8 & & & \\
\hline
\end{tabular}

Çalışmada araştırmaya katılanların demografik bilgilerine göre karşılaştırma analizlerine de yer verilmiştir. Çalışanların iş yükü fazlalığı, iş-aile çatışması ve yaşam kalitesine ilişkin algılarının cinsiyet ve medeni durum değişkenine göre fark gösterip göstermediğini belirlemek amacıyla Mann Whitney $U$ testi yapılmıştır. Ayrıca, yaş, öğrenim durumu, meslekte çalışma süresi, kurumda çalışma süresi, unvan, haftalık çalışma süresi, çalışma şekli, çalışılan il değişkenlerine göre farklılık bulunup bulunmmadığını tespit etmek için de Kruskal Wallis testi yapılmıştır. 
Tablo 4. Cinsiyet ve Medeni Durum İçin Yapılan Mann Whitney U Testi:

\begin{tabular}{|c|c|c|c|c|c|}
\hline & Cinsiyet & $\mathbf{N}$ & Sira Ort. & $\mathbf{u}$ & p \\
\hline İş Yükü Fazlalı̆̆ı & $\begin{array}{l}\text { Kadın } \\
\text { Erkek }\end{array}$ & $\begin{array}{l}517 \\
478\end{array}$ & $\begin{array}{l}480,37 \\
517,07\end{array}$ & 114446,50 &, $044^{*}$ \\
\hline İş-Aile Çatışması & $\begin{array}{l}\text { Kadın } \\
\text { Erkek }\end{array}$ & $\begin{array}{l}517 \\
478\end{array}$ & $\begin{array}{l}477,19 \\
520,50\end{array}$ & 112806,00 &, $017^{*}$ \\
\hline Yaşam Kalitesi & $\begin{array}{l}\text { Kadın } \\
\text { Erkek }\end{array}$ & $\begin{array}{l}517 \\
478\end{array}$ & $\begin{array}{l}485,73 \\
511,27\end{array}$ & 117221,00 & 161 \\
\hline & Medeni Durum & & 2 & & \\
\hline İş Yükü Fazlalığı & $\begin{array}{l}\text { Evli } \\
\text { Bekâr }\end{array}$ & $\begin{array}{l}543 \\
452\end{array}$ & $\begin{array}{l}504,33 \\
490,40\end{array}$ & 119283,00 & ,446 \\
\hline İş-Aile Çatışması & $\begin{array}{l}\text { Evli } \\
\text { Bekâr }\end{array}$ & $\begin{array}{l}543 \\
452\end{array}$ & $\begin{array}{l}505,56 \\
488,92\end{array}$ & 118613,50 & ,363 \\
\hline Yaşam Kalitesi & $\begin{array}{l}\text { Evli } \\
\text { Bekâr }\end{array}$ & $\begin{array}{r}543 \\
452\end{array}$ & $\begin{array}{l}510,80 \\
482,62\end{array}$ & 115766,50 & 123 \\
\hline
\end{tabular}

Tablo 4'e göre; katılımcıların, cinsiyet grupları arasında iş yükü fazlalığı ve iş-aile çatışması puanı açısından istatistiki açıdan anlamlı bir fark vardır $(p<0,05)$. Bu sonuçlara göre erkeklerin yaşadığı iş yükü fazlalığı ve iş-aile çatışması kadınlara nazaran daha yüksektir. Katılımcıların, cinsiyet grupları arasında yaşam kalitesi açısından istatistiki açıdan anlamlı bir fark vardır $(\mathrm{p}>0,05)$. Katılımcıların, medeni durum grupları arasında iş yükü fazlalığı, iş-aile çatışması ve yaşam kalitesi puanları bakımından istatistiki açıdan anlamlı bir fark vardır $(p>0,05)$.

Tablo 5'e göre; katılımcıların, yaş grupları arasında iş yükü fazlalığı ve iş aile çatışması puanı bakımından istatistiki açıdan anlamlı bir fark varken $(p<0,05)$, yaşam kalitesi puanları bakımından ise istatistiki açıdan anlamlı bir fark yoktur ( $p>0,05)$. Katılımcıların, öğrenim durumu grupları arasında iş yükü fazlalığı ve yaşam kalitesi puanı bakımından istatistiki açıdan anlamlı bir fark varken $(p<0,05)$, iş-aile çatışması puanları bakımından istatistiksel olarak anlamlı bir fark yoktur $(p>0,05)$. Katılımcıların, unvan grupları arasında iş yükü fazlalığı ve iş-aile çatışması puanı bakımından istatistiki açıdan anlamlı bir fark varken $(p<0,05)$, yaşam kalitesi puanları bakımından ise istatistiki açıdan anlamlı bir fark yoktur $(p>0,05)$. 
Tablo 5. Yaş, Unvan ve Öğrenim Durumu İçin Kruskal Wallis Testi

\begin{tabular}{|c|c|c|c|c|c|}
\hline & Yaş & $\mathbf{N}$ & Sira Ort. & $\mathrm{X}^{2}$ & p \\
\hline \multirow{5}{*}{ İş Yükü Fazlalığı } & $18-25$ & 289 & 436,16 & \multirow{5}{*}{31,982} & \multirow{5}{*}{, $000^{*}$} \\
\hline & $26-30$ & 285 & 490,00 & & \\
\hline & $31-35$ & 179 & 585,55 & & \\
\hline & $36-40$ & 165 & 526,38 & & \\
\hline & $41+$ & 77 & 495,35 & & \\
\hline \multirow{5}{*}{ İş-Aile Çatışması } & $18-25$ & 289 & 443,42 & \multirow{5}{*}{25,397} & \multirow{5}{*}{, $000^{*}$} \\
\hline & $26-30$ & 285 & 482,68 & & \\
\hline & $31-35$ & 179 & 557,88 & & \\
\hline & $36-40$ & 165 & 554,25 & & \\
\hline & $41+$ & 77 & 499,79 & & \\
\hline \multirow{6}{*}{ Yaşam Kalitesi } & $18-25$ & 289 & 478,08 & & \multirow{5}{*}{,104 } \\
\hline & $26-30$ & 285 & 513,49 & & \\
\hline & $31-35$ & 179 & 526,40 & 7,678 & \\
\hline & $36-40$ & 165 & 504,44 & & \\
\hline & $41+$ & 77 & 435,64 & & \\
\hline & \multicolumn{5}{|c|}{ Öğrenim Durumu } \\
\hline \multirow{3}{*}{ İş Yükü Fazlalığı } & Lise & 166 & 482,14 & \multirow{3}{*}{15,141} & \multirow{3}{*}{, $002^{*}$} \\
\hline & Ön lisans & 312 & 460,50 & & \\
\hline & $\begin{array}{l}\text { Lisans } \\
\text { Lisansüstü }\end{array}$ & $\begin{array}{l}432 \\
85\end{array}$ & $\begin{array}{l}513,91 \\
585,77\end{array}$ & & \\
\hline \multirow{3}{*}{ İş-Aile Çatışması } & Lise & 166 & 509,01 & \multirow{3}{*}{1,748} & \multirow{3}{*}{,626 } \\
\hline & Ön lisans & 312 & 486,79 & & \\
\hline & $\begin{array}{l}\text { Lisans } \\
\text { Lisansüstü }\end{array}$ & $\begin{array}{l}432 \\
85\end{array}$ & $\begin{array}{l}495,73 \\
529,15\end{array}$ & & \\
\hline \multirow{5}{*}{ Yaşam Kalitesi } & Lise & 166 & 452,02 & \multirow{4}{*}{13,162} & \multirow{4}{*}{, $004^{*}$} \\
\hline & Ön lisans & 312 & 522,23 & & \\
\hline & Lisans & 432 & 483,65 & & \\
\hline & Lisansüstü & 85 & 571,80 & & \\
\hline & Unvan & & & & \\
\hline \multirow{3}{*}{ İş Yükü Fazlalığ1 } & Tabip & 94 & 624,20 & \multirow{3}{*}{29,957} & \multirow{3}{*}{, $000^{*}$} \\
\hline & $\begin{array}{l}\text { Pers } \\
\text { Pers DII Sag }\end{array}$ & 754 & 471,60 & & \\
\hline & İdari Personel & 147 & 552,70 & & \\
\hline \multirow{3}{*}{ İş-Aile Çatışması } & Tabip & 94 & 544,48 & \multirow{3}{*}{14,168} & \multirow{3}{*}{, $001^{*}$} \\
\hline & Tabip Dışı Sağlik & 754 & 478,87 & & \\
\hline & $\begin{array}{l}\text { Pers } \\
\text { İdari Personel }\end{array}$ & 147 & 566,41 & & \\
\hline \multirow{3}{*}{ Yaşam Kalitesi } & Tabip & & & \multirow{3}{*}{2,319} & \multirow{3}{*}{,314 } \\
\hline & Tabip Dışı Sağlık & 754 & 499,73 & & \\
\hline & $\begin{array}{l}\text { Pers } \\
\text { İdari Personel }\end{array}$ & 147 & 470,61 & & \\
\hline
\end{tabular}


Tablo 6. Meslekte ve Kurumda Çalışma Süresi, Haftalık Çalışma Süresi ve Çalışma Şekli İçin Kruskal Wallis Testi:

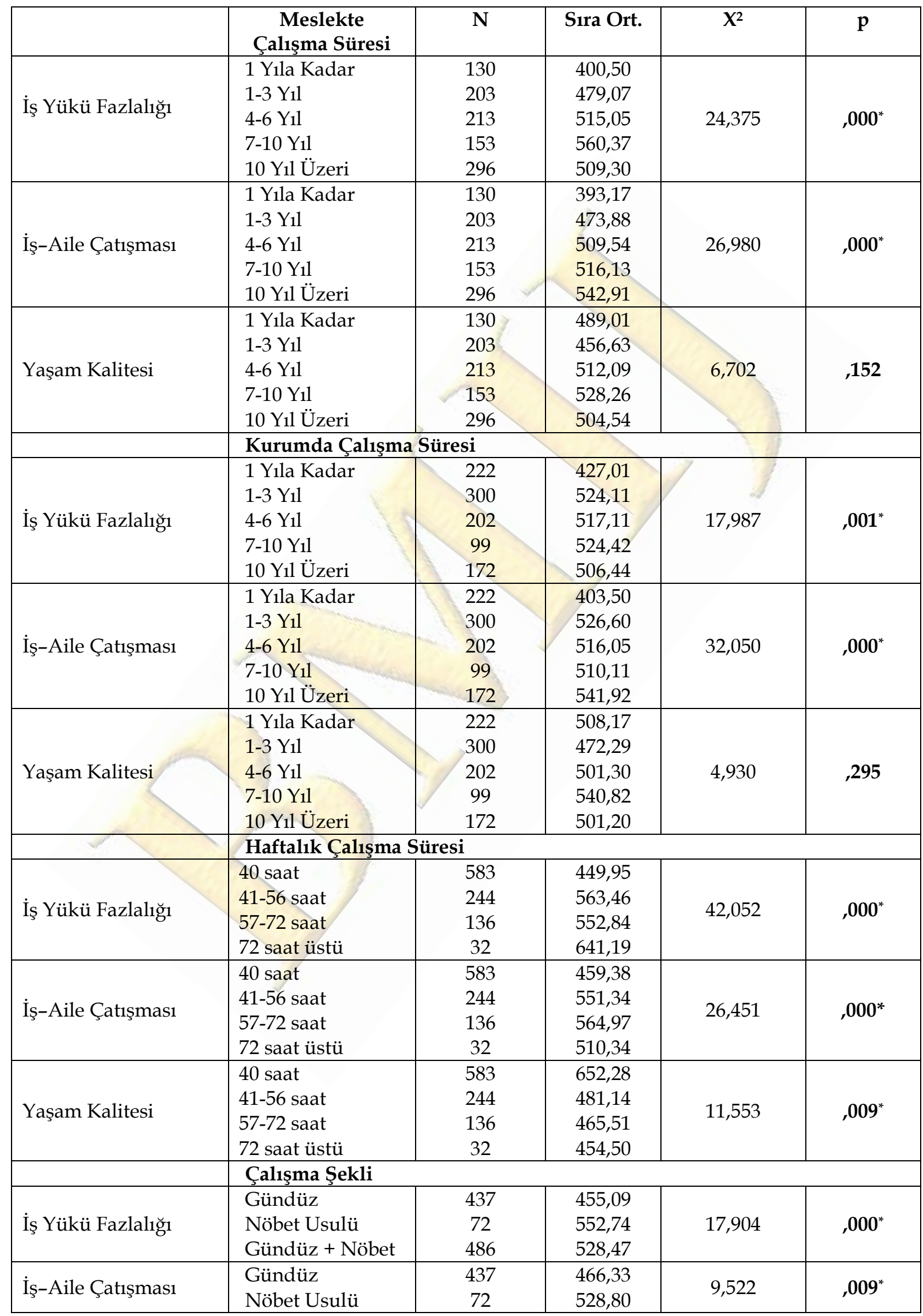




\begin{tabular}{|c|c|c|c|c|c|}
\hline & Gündüz + Nöbet & 486 & 521,91 & & \\
\hline Yaşam Kalitesi & $\begin{array}{l}\text { Gündüz } \\
\text { Nöbet Usulü } \\
\text { Gündüz + Nöbet }\end{array}$ & $\begin{array}{c}437 \\
72 \\
486\end{array}$ & $\begin{array}{l}510,33 \\
452,31 \\
493,68\end{array}$ & 2,737 & 254 \\
\hline
\end{tabular}

Tablo 6’ya göre; katılımcıların, meslekte çalışma süresi ve kurumda çalışma süresi grupları arasında iş yükü fazlalığı ve iş aile çatışması puanı bakımından istatistiki açıdan anlamlı bir fark varken $(p<0,05)$, yaşam kalitesi puanları bakımından ise istatistiki açıdan anlamlı bir fark yoktur $(p>0,05)$. Katılımcıların, çalışma şekli grupları arasında iş yükü fazlalığı ve iş aile çatışması puanı bakımından istatistiki açıdan anlamlı bir fark varken $(\mathrm{p}<0,05)$, yaşam kalitesi puanları bakımından ise istatistiki açıdan anlamlı bir fark yoktur $(p>0,05)$. Katılımcıların, haftalık çalışma süresi grupları arasında iş yükü fazlalığı, iş aile çatışması ve yaşam kalitesi puanları bakımından istatistiki açıdan anlamlı bir fark vardir $(p<0,05)$.

\subsection{Değişkenler Arasındaki Korelasyonlarve Regresyon Analizi Sonuçları}

Tablo 7. YEM ile Regresyon Analizi Sonuçları

\begin{tabular}{|c|c|c|c|c|c|c|}
\hline Bağımlı & & Bağımsız & Estimate & S.E. & C.R. & $\mathbf{P}$ \\
\hline İşten Aileye Çatışma & & İş Yükü Fazlalığg & 703 & ,047 & 14,951 & $* * *$ \\
\hline Aileden İşe Çatışma & $<--$ & İş Yükü Fazlalığ1 & 177 & ,027 & 6,520 & $* * *$ \\
\hline Yaşam Kalitesi & $<--$ & İş Yükü Fazlalığı &,- 037 & ,031 & $-1,190$ & ,234 \\
\hline Yaşam Kalitesi & $<--$ & $\begin{array}{c}\text { İşten Aileye } \\
\text { Çatışma }\end{array}$ &,- 084 & ,031 & $-2,709$ & $* * *$ \\
\hline Yaşam Kalitesi & $<---$ & Aileden İşe Çatışma &,- 136 & ,037 & $-3,680$ & $* * *$ \\
\hline
\end{tabular}

Tablo 7'ye göre; İş yükü fazlalığı, işten aileye çatışma ve aileden işe çatışma boyutlarını pozitif olarak anlamlı artırmaktadır. İşten aileye çatışma ve aileden işe çatışma Yaşam kalitesini anlamlı olarak azaltmaktadır. İş yükü fazlalığının, Yaşam kalitesini etkilemesinde işten aileye çatışmanın anlamlı olarak aracılık ettiği belirlenmiştir (Sobel Test İstatistiği=4.102, p<0,05). İş yükü fazlalı̆̆ının, Yaşam kalitesini etkilemesinde ve aileden işe çatışmanın anlamlı olarak aracılık ettiği belirlenmiştir (Sobel Test İstatistiği=3.234, p<0,05). İş yükü fazlalığının, Yaşam kalitesi üzerindeki doğrudan etki katsayısı -,037 olarak hesaplanmıştır. Aracılık etkisi 
gösteren işten aileye çatışma modele eklendiğinde dolaylı etki 0,162 ve aileden işe çatışma eklendiğinde dolaylı etki 0,184 olarak hesaplanmıştır. Etki düzeyi arttı̆̆ından dolayı tam aracılık söz konusudur.

Tablo 8. Değişkenler Arasındaki Pearson Korelasyon Analizi

\begin{tabular}{|c|c|c|c|c|c|}
\hline & & $\begin{array}{l}\text { İş Yükü } \\
\text { Fazlalığ́1 }\end{array}$ & $\begin{array}{c}\text { İşten Aileye } \\
\text { Çatışma }\end{array}$ & $\begin{array}{c}\text { Aileden İşe } \\
\text { Çatışma }\end{array}$ & $\begin{array}{l}\text { Yaşam } \\
\text { Kalitesi }\end{array}$ \\
\hline İş Yükü Fazlalığı & $\begin{array}{l}\text { Correlation } \\
\text { Sig. (2-tailed) }\end{array}$ & 1,000 & $\begin{array}{l}, 586^{* *} \\
, 000\end{array}$ & $\begin{array}{l}\text {,265** } \\
, 000\end{array}$ & $\begin{array}{c}-, 175^{* *} \\
, 000\end{array}$ \\
\hline $\begin{array}{c}\text { İşten Aileye } \\
\text { Çatışma }\end{array}$ & $\begin{array}{l}\text { Correlation } \\
\text { Sig. (2-tailed) }\end{array}$ & & 1,000 & $\begin{array}{l}, 127^{* *} \\
, 000\end{array}$ & $\begin{array}{c}-, 184^{* *} \\
, 000\end{array}$ \\
\hline Aileden İşe Çatışma & $\begin{array}{l}\text { Correlation } \\
\text { Sig. (2-tailed) }\end{array}$ & & & 1,000 & $\begin{array}{c}-, 180^{* *} \\
, 000\end{array}$ \\
\hline Yaşam Kalitesi & $\begin{array}{l}\text { Correlation } \\
\text { Sig. (2-tailed) }\end{array}$ & & & & 1,000 \\
\hline
\end{tabular}

Tablo 8'e göre; İş yükü fazlalığı ile işten aileye çatışma ve aileden işe çatışma arasında pozitif yönlü orta kuvvette bir ilişki vardır. İş yükü fazlalığı ile yaşam kalitesi arasında ise negatif yönlü zayıf bir ilişki vardır. İşten aileye çatışma ile aileden işe çatışma arasında pozitif yönlü zayıf bir ilişki vardır. İşten aileye çatışma ile aileden işe çatışma ve yaşam kalitesi arasında negatif yönlü zayıf bir ilişki vardır.

\subsection{Yapısal Eşitlik Modeline İlişkin Bulgular}

YEM'e ait uyum indeks değerleri ve programın önerdiği modifikasyon önerisi de dikkate alınarak model Şekil 2' deki son halini almıştır.

Şekil 2' de oklar üzerinde yer alan sayılar path katsayılarıdır. Path katsayıları, standartlaştırılan regresyon katsayılarıdır. Bir path katsayısı, bağımsız değişkendeki bir standart sapmalık değişimin bağımlı değişkende yaratacağı sapma miktarını gösterir. Bu açıklamalar 1şığında işyükü fazlalığı IYA ölçeğine bakıldığında iş- aile çatışması IAC değişkeninin $(\beta$ : 0,70) en yüksek etkiye, yaşam kalitesi YK değişkeninin $(\beta: 0,04)$ ise en düşük etkiye sahip olduğu söylenebilir. 


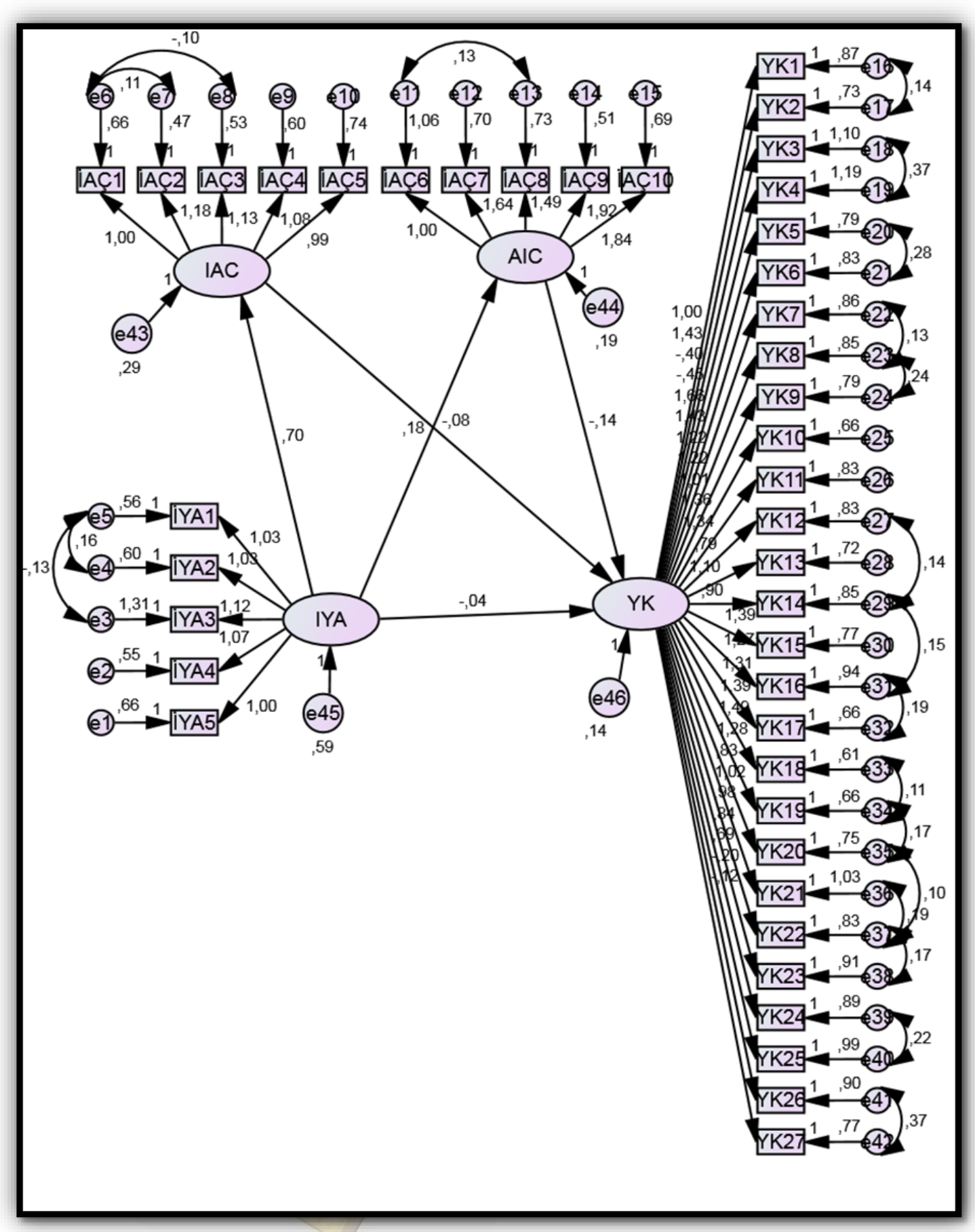

Şekil 2. Araştırmaya Ait Yapısal Eşitlik Modeli

Bu sonuçlara göre; hipotezlerin durumu (0,05 anlamlılık düzeyinde) aşağıdaki gibidir.

H1: İşÿ̈kü fazlalığı algısının yaşam kalitesi üzerindeki etkisinde iş-aile çatışmasının aracı rolü vardır hipotezi kabul edilmiştir.

$\mathbf{H}_{2}$ İ̧̧ yükü fazlahı̆̆ yaşam kalitesini etkiler hipotezi red edilmiştir. 


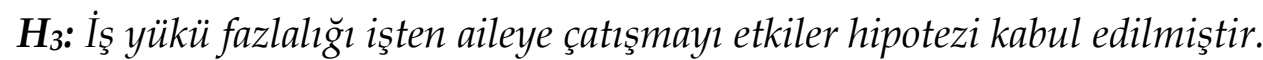

H4: İş yükü fazlalı̆̆̆ aileden işe çatışmayı etkiler hipotezi kabul edilmiştir.

H5: Aileden işe çatışma yaşam kalitesini etkiler hipotezi kabul edilmiştir.

$\mathbf{H}_{6}$ İşten aileye çatışma yaşam kalitesini etkiler hipotezi kabul edilmiştir.

H7: Demografik bilgilere göre, iş yükü fazlalı̆̆ı algısı farklılık gösterir hipotezi kısmen kabul edilmiştir.

$H_{8}$ : Demografik bilgilere göre, iş-aile çatışması farklılık gösterir hipotezi kısmen kabul edilmiştir.

H9: Demografik bilgilere göre, yaşam kalitesi algısı farklılık gösterir hipotezi kısmen kabul edilmiştir.

\section{SONUÇ VE TARTIŞMA}

Çalışma hayatı bireyin günlük yaşantısı üzerinde önemli etkilere sahiptir. Günün önemli bir kısmını iş yerinde geçirmenin ötesinde, genellikle iş, bireyin düşüncelerini meşgul etmekte, günlük programını belirlemekte, sosyal kimliğine katkıda bulunmakta ve hatta bazı durumlarda bir aileye sahip olup olamayacağının kararını bile etkileyebilmektedir.

Araştırmanın bulgular kısmında, iş yükü fazlalığı, yaşam kalitesi ve iş-aile çatışması değişkenlerine ilişkin tanımlayıcı bulgular sunulduktan sonra sağlık çalışanlarının iş yükü fazlalığının, yaşam kalitesi üzerindeki etkisinde iş-aile çatışmasının aracı etkisi analiz edilmiştir. Araştırmada ayrıca, sağlık çalışanlarının iş yükü fazlalığı, yaşam kalitesi ve iş-aile çatışması düzeylerinin yaş, cinsiyet, medeni durum, öğrenim durumu, meslekte ve kurumda çalışma süresi, unvan, çalışma şekli, haftalık çalışma süresi, görev yapılan hastanenin bulunduğu il değişkenlerine göre fark gösterip göstermediği de incelenmiştir. Çalışanların iş yükü fazlalığı, iş-aile çatışması ve yaşam kalitesine ilişkin algılarının sosyo demografik değişkenine göre farklılık gösterip göstermediğini tespit etmek için Mann Whitney ve Kruskal Wallis testi yapılmıştır. Bu çerçevede yapılan analizler sonucu elde edilen bulgulara ilişkin tartışmalara yer verilmiştir. 
İş yükü fazlalığının demografik özelliklerle ilişkisini incelemek için yapılan analiz sonucunda; medeni durum açısından iş yükü fazlalığı istatistiki olarak anlamlı bir fark bulunmamaktadır. Yaş, cinsiyet, öğrenim durumu, meslekte ve kurumda çalışma süresi, unvan, haftalık çalışma süresi çalışma şekli ve çalışılan il değişkenleri arasında istatistiki olarak anlamlı bir fark bulunmaktadır. Bu sonuçlara göre erkeklerin iş yükü fazlalığı algısı puanı sıra ortalaması kadınlara nazaran daha yüksektir. Çalışanların eğitim düzeyi yükseldikçe iş yükü fazlalığına dair algılarında olumsuz yönde bir yükselme eğilimi söz konusu olmaktadır. 1 yıldan az çalışanların puan sıra ortalaması en düşük iken meslekte çalışma süresi arttıkça iş yükü fazlalığı algısı da artmaktadır. 10 yıldan fazla süredeki çalışanların iş yükü fazlalığı algısı ise en düşük ikinci sıradadır. Bu durum meslekte çalışma süresi fazla olan sağlık çalışanlarının daha çok nöbeti olmayan, rutin işlerin yapıldı̆̆ 1 veya hasta yoğunluğunun az olduğu pasif birimlerde görevlendirilmesi şeklinde değerlendirilebilir. Tabiplerin iş yükü fazlalığı algısı tabip dışı sağlık personeli ve idari personele göre daha yüksektir. Bu sonuçlara göre tabip dışı sağlık personelinin iş yükü fazlalığını en düşük oranda algılarken tabiplerin iş yükü fazlalığını en yüksek oranda algıladığı tespit edilmiştir. Gündüz çalışan sağlık personeli daha çok rutin işler yapıldığı için iş yükü fazlalığı algısı en düşük iken, nöbet usulü çalışan sağlık personelinin ise yapılan işler karmaşık ve görev dağılımının net olmaması sonucu iş yükü fazlalığı algısı en yüksektir. İş yükü fazlalığı algısının çalışılan hastanenin büyüklüğü ve çalışılan kurumun kurumsal yapısından etkilendiği şeklinde değerlendirilebilir. Bu kapsamda, aşırı iş yükü algısını doğurabilecek baskılar yeniden değerlendirilmeli, iş talepleri ile çalışanların kapasiteleriarasında uyumun olması dikkate alınmalıdır.

İş-aile çatışmasının demografik özelliklerle ilişkisini incelemek için yapılan analiz sonucunda; medeni durum açısından iş-aile çatışması algıları açısından istatistiki olarak anlamlı bir fark bulunmamaktadır. Yaş, cinsiyet, öğrenim durumu, meslekte ve kurumda çalışma süresi, unvan, haftalık çalışma süresi çalışma şekli ve çalışılan il değişkenleri arasında istatistiki olarak anlamlı bir fark bulunmaktadır. Bu bulgu cinsiyet açısından benzer araştırmalar ile uyumludur (Bragger vd, 2005; Karatepe ve Kılıç, 2005; Cinamon and Rich, 2005; Zincirkıran, 2013). Yaş grupları 
açısından benzer araştırmalar ile uyumludur (Giray ve Ergin, 2006). Bu durumun genç olanların yeni evli olduğu için henüz iş-aile yaşamını dengeleyememesi ve yaşı büyük olanların daha deneyimli olduğu için iki alan arasındaki dengeyi daha kolay sağlayabilmesinden kaynaklandığı tespit edilmiştir. Aynı zamanda yaşı büyük çalışanların çalışma saatlerinin daha düzenli olması da yaşanan çatışma düzeyini azaltmaktadır. Meslekte çalışma süresi ve kurumda çalışma süresi grupları açısından benzer araştırmalar ile uyumludur (Sönmez vd., 2015). Meslekte ve kurumda çalışma süresi arttıkça yaşanan iş-aile çatışması düzeyi de artmaktadır. Bu durum meslekte ve kurumda çalışma süresi fazla olan sağlık çalışanlarının daha çok yıprandı̆̆ı, mesleki doyumlarının giderek azaldığı ve iş-aile dengesini kurmada daha fazla zorlandıkları şeklinde değerlendirilebilir. Katılımcıların, haftalık çalışma süresi grupları açısından benzer araştırmalar ile uyumludur (Sönmez vd., 2015). Bu sonuçlara göre haftalık çalışma süresi arttıkça yaşanan iş-aile çatışması düzeyi de artmaktadır. Bu durum haftalık çalışma süresi fazla olan sağlık çalışanlarının iş-aile dengesini kurmada daha fazla zorlandıkları şeklinde değerlendirilebilir. Çalışma şekli açısından benzer araştırmalar ile uyumludur (Sönmez vd., 2015). Bu sonuçlara göre gündüz çalışan sağlık personeli normal çalışma saatlerinde çalıştıkları, aile ve diğer sosyal sorumluluklarına yeterli zaman ayırabildikleri için iş-aile çatışmasını yaşama düzeyleri düşüktür. Nöbet usulü çalışan sağlık personelinin ise çalışma saatleri aile ve diğer sosyal sorumluluklarına yeterli zaman ayırmalarına engel olduğu için iş-aile çatışması yaşanma düzeyi en yüksektir. Katılımcıların, çalıştığı illere göre iş-aile çatışması yaşanma düzeyinin farklı olması, iş-aile çatışması yaşanma düzeyinin çalışılan hastane yönetiminin oluşturduğu kurumsal kültür ve çalışma ikliminden etkilendiği şeklinde değerlendirilebilir.

Yaşam kalitesinin demografik özelliklerle ilişkisini incelemek için yapılan analiz sonucunda; katılımcıların, yaş, cinsiyet, medeni durum, meslekte ve kurumda çalışma süresi, unvan ve çalışma şekli açısından yaşam kalitesi faktörlerini değerlendirmesinde bir farklılık görülmemiştir. Bu bulgu benzer araştırmalar ile uyumlu iken (Chien vd, 2003; Avc1, Pala 2004; Kaya, 2004), uyumlu olmadiğ1 çalışmalara da rastlamak mümkündür (Yıldırım ve Hacıhasanoğlu, 2011). Bu sonuca göre, hizmet süresi arttıkça çalışanların yüksek beklentileri ve enerjileri yıllar 
geçtikçe azalarak iş doyumu düşüşüne neden olabilmekte ve yaşam kalitesini olumsuz etkileyebilmektedir. Katılımcıların eğitim durumu, haftalık çalışma süresi ve çalışılan il değişkenleri arasında yaşam kalitesi bakımından istatistiksel olarak anlamlı bir fark bulunmaktadır. Bu bulgu benzer araştırmalar ile uyumludur (Meeks ve Murrell, 2001). Bu durum eğitim düzeyi düşük olan sağlık çalışanlarının kaliteli bir yaşam sürmekte daha fazla zorlandıkları eğitim düzeyi yüksek olan sağlık çalışanlarının ise kaliteli bir yaşam sürmekte daha az zorlandıkları şeklinde değerlendirilebilir. Bu sonuçlara göre haftalık 40 saat gündüz çalışan sağlık personeli normal çalışma saatlerinde çalıştıkları, aile ve diğer sosyal sorumluluklarına yeterli zaman ayırabildikleri için yaşam kalitesi düzeyleri diğer çalışanlara nazaran daha yüksektir. Başka bir ifade ile haftalık çalışma süresi arttıkça yaşam kalitesi düzeyi de düşmektedir. Bu durum haftalık çalışma süresi fazla olan sağlık çalışanlarının kaliteli bir yaşam sürmekte daha fazla zorlandıkları şeklinde değerlendirilebilir. Katılımcıların, çalıştığı illere göre bakıldığında yaşam kalitesi düzeyi farklılaşmaktadır.

Çalışmanın ileride yapılacak çalışmalara da yol göstermesi beklenmektedir. Araştırma, sadece sağlık sektöründeki çalışanlar üzerinde yapıldığından, sağlık sektörü dışındaki sektörlere de uygulanması konunun gelişimine katkı sağlayacaktır. Bu çalışma Türkiye' de TRB-2 bölgesindeki uygulanmıştır. Tüm sağlık çalışanları ile ilgili genelleme yapılabilmesi için, TRB-2 bölgesi dışındaki bölgelerin sağlık çalışanlarına da benzer bir çalışmanın uygulanması konuya katkı sağlayacaktır. 


\section{KAYNAKÇA}

Alam, M. A. (2016) Techno-Stress and Productivity: Survey Evidence From the Aviation Industry. Journal of Air Transport Management, 50(1), 62-70.

Alpar, R. (2014). Uygulamalı İstatistik ve Geçerlilik-Güvenilirlik, (3. Baskı), Detay Yayıncılık, Ankara. Apaydın, M.D. (2004) Çift Kariyerli Ailelerde İş-Aile ve Aile-I่̧ş Çatışmalarının Kendini Kurgulama Düzeyleri İle İlişkisi, Yüksek Lisans Tezi, Hacettepe Üniversitesi Sosyal Bilimler Enstitüsü, Ankara.

Avcı, K. ve Pala, K. (2004) Uludağ Üniversitesi Tıp Fakültesinde Çalışan Araştırma Görevlisi ve Uzman Doktorların Yaşam Kalitesinin Değerlendirilmesi, Uludağ Üniversitesi Tıp Fakültesi Dergisi, 30(2), 81-85.

Barron DN. and West E. (2007) The Emotional Costs of Caring İncurred by Men and Women in the British Labour Market. Soc Sci Med, 65(21), 60-71.

Bragger, J.D., Srednicki, O.R., Kutcher, E.J. (2005) “Work- Family Conflict, Work-Family Culture And Organizational Citizenship Behaviour Among Teachers", Journal of Business and Psychology, 20(2), 303-324.

Chien LY, Lo LH, Chen CJ, Chen YC, (2003) "Quality of Life Among Primary Caregivers of Taiwanese Children with Brain Tumor", Cancer Nurs, 26, 305-311.

Cinamon, GR. and Rich, Y. (2005) Work Family Conflict among Female Teachers. Teaching and Teacher Education, 21(4), 365-378.

Çarıkçı, İ.H. ve Çelikkol, Ö. (2009) İş-Aile çatışmasının Örgütsel Bağlılık ve İşten Ayrılma Niyetine Etkisi. Süleyman Demirel Üniversitesi Sosyal Bilimler Enstitüsü Dergisi, 1(9), 153-170.

Eroğlu, F. (2007), Davranış Bilimleri, (7. Baskı), Beta Basım Yayım Dağıtım, İstanbul.

Fidaner, H., Elbi, H., Fidaner, C., Eser, S.Y., Eser, E., Göker, E “WHOQOL-100 ve WHOQOL-Bref' in Psikometrik Özellikleri", Psikiyatri Psikoloji Psikofarmakoloji (3P) Dergisi, 1999/7 (Ek2), 23-40.

French SE, Lenton R, Walters V, Eyles J. (2000) An Empirical Evaluation of an Expanded Nursing Stress Scale. J Nurs Meas, 8(2), 161-178.

Fu, CK. and Shaffer, MA. (2000) The Tug of Work and Family Direct and Indirect Domain Specific Determinants of Work Family Conflict. Personnel Review, 30(5), 502- 522.

Giray, MD. ve Ergin, C. (2006) Çift Kariyerli Ailelerde Bireylerin Yaşadıkları İş- Aile ve Aile-İşs Çatışmalarının Kendini Kurgulama Davranışı ve Yaşama Olayları ile İlişkisi, Türk Psikoloji Dergisi, 21 (57), 83-107.

Greenhaus, J. and Beutell, NJ. (1985) Sources of Conflict Between Work and Family Roles, The Academy of Management Review, 10(1),76-88. 
Hobfoll, SE. (1989) Conservation of Resources: A new Attempt at Conceptualizing Stress, American Psychologist, 44, 513-524.

Hobfoll, SE. (2001), The Influence of Culture, Community, and the NestedSelf in the Stress Rocess: Advancing Conservation of Resources Theory. Applied Psychology: An International Review, 50 (3), $337-421$

İmoisili, OA. (1985). Task Complexity, Budget Style of Evaluating Performance and Managerial Stress: an Empirical Investigation. Ph.D. dissertation. University of Pittsburgh

Kaçmaz N. (2005) Tükenmişlik Sendromu, İstanbul Tıp Fakültesi Dergisi, 68, 29-32.

Karoshı, (2003) Reduce Stress, Workload and Work Time and İmprove Work-Life Balance Before İt's Too Late, Hot Topics in Collective Bargaining Issues, Public Servise for Alliance of Canada, 5, 1-19.

Katyayani, J. and Bussareddy, V. (2011) Work-Family Conflıct Among Paramedical Staff, Mustang Journal of Business \& Ethics, 2, 121-127.

Kaya, M. (2004) Ankara'da 112 Acil Yardım Hizmetleri Sağlık Çalışanlarının Öznel Yaşam Kalitelerinin Değerlendirilmesi, Sağlık ve Toplum Dergisi,14 (4),1-14.

Keser, A. (2005) The Relationship Between Job and Life Satisfaction in Automobile Sector Employees in Bursa - Turkey, İş-Güç Endüstri İlişkileri ve İnsan Kaynakları Dergisi, 7 (2), 52-63

Keser, A. (2006) Çağrı Merkezi Çalışanlarında İş Yükü Düzeyi İle İş Doyumu İlişkisinin Araştırılması", Kocaeli Üniversitesi Sosyal Bilimler Enstitüsü Dergisi, 11(1), 100-119

Lydon, J., Pierce, T. and O'regan, S., (1997) Coping With Moral Commitment to Longdistance Dating Relationship", Journal of Personality and Social Psychology, 73, 104-113.

Madsen, R.S. (2003) The Effects of Home Based Teleworking on Family Conflict, Human Resource Development Quarterly, 14 (1), 35-58.

Meeks S, and Murrell SA. (2001) Contribution of Education to Health and Life Satisfaction in Older Adults Mediated by Negative Affect, J Aging Health, 13, 92-119.

Meydan, CH. ve Şeşen, H. (2015), Yapısal Eşitlik Modellemesi - AMOS Uygulamaları, Detay Yayıncilik, Ankara.

Netemeyer, G. Richard., Boles, S. James., McMurrian, R. (1996) Development and Validation of Work Family Conflict and Family Work Conflict Scales, Journal of Applied Psychology, 81 (4), 400-410.

Özkalp, E. ve Kırel, Ç. (2013). Örgütsel Davranış, 6. Baskı, Ekin Kitabevi Yayınları Bursa.

Schulze, N. (1998) Yaşam Kalitesini Yükselten Temel Unsur Olarak İşin İnsancıllaştırılması, 6. Ergonomi Kongresi, MPM Yayınları No: 622, 519-532. 
Sönmez, H. Er, F. ve Eryılmaz, H. (2015) Hemşirelerde İş-Aile Çatışmasının Farklı Demografik Özelliklerle İlişkisinin Correspondence Analiziyle Belirlenmesi, Aksaray Üniversitesi İktisadi ve İdari Bilimler Fakültesi Dergisi, 7 (3), 1-8

Syed Saad, HS. Ahsan, RJ. Jabran, A. Wasiq, E. Ihsan, U. and Syed NR. (2011) Workload and Performance of Employees, Interdısciplınary Journal of Contemporary Research in Busıness, 3 (5), 256267

Şenol Y. ve Türkay M. (2006) Yaşam Kalitesi Ölçütlerinde Taraf Tutma: Cevap Kayması, TAF Preventive Medicine Bulletin, 5(5), 382- 389

Wallace, JE. (1999) Work-to-Nonwork Conflict Among Married Male and Female Lawyers", Journal of Organizational Behavior. 20, 797-816.

Yıldırım, A. ve Hacıhasanoğlu R. (2011) Sağlık Çalışanlarında Yaşam Kalitesi ve Etkileyen Değişkenler, Psikiyatri Hemşireliği Dergisi, 2 (2), 61-68

Yazıcıoğlu, Y. ve Erdoğan, S. (2014). SPSS Uygulamalı Bilimsel Araştırma Yöntemleri, (4. Baskı), Detay Yayıncilık, Ankara.

Yıldırımçakar, Ş. (2015) Sağlık Çalışanları ve Yaşam Kalitesi, Yüksek Lisans Tezi, Beykent Üniversitesi, Sosyal Bilimler Enstitüsü, İstanbul.

Yüksel, Ö. (2003) İnsan Kaynakları Yönetimi, Gazi Kitabevi, Ankara.

Yüksel, İ. (2005) İş Aile Çatışmasının Kariyer Tatmini ve İş Tatmini Davranışları ile İlişkisi, İktisadi ve İdari Bilimler Dergisi, 19 (2), 301- 314.

Yürür, Ş. (2011) Öğrenilmiş Güçlülük, Kıdem ve Medeni Durumun Duygusal Tükenmedeki Rolü: Kaynakların Korunması Teorisi Kapsamında Bir Analiz, Atatürk Üniversitesi İktisadi ve İdari Bilimler Dergisi, 25 (1), 107-126

Zincirkıran, M. (2013) İşkoliklik İle İş-Aile Çatışması İlişkisinin Yapısal Eşitlik Modeli İle İncelenmesi: Sağlık İşletmelerinde Bir Uygulama, Doktora Tezi, Dicle Üniversitesi, Sosyal Bilimler Enstitüsü, Diyarbakır. 